\title{
A ética do inconcluso em juventude em marcha - a carta de Ventura
}

The ethics of the inconclusive in colossal youth - Ventura's letter

João Luiz Borogan Cerqueira ${ }^{1}$

\footnotetext{
${ }^{1}$ Doutorando no Programa de Pós-Graduação de Meios e Processos Audiovisuais da Escola de Comunicação e Artes da Universidade de São Paulo (ECA/USP) e mestre em Culturas e Identidades Brasileiras pela USP (2019). E-mail: joao.borogan@gmail.com
} 
Resumo: Este ensaio apresenta uma análise do personagem Ventura, de Juventude em marcha, à luz das considerações de Bakhtin sobre a construção da personagem no romance polifônico de Dostoievski. O comentário se centrará, sobretudo, na carta de Ventura e em sua possível leitura analítica como uma porta de entrada para comentarmos a constituição dessa personagem como uma autoconsciência. A hipótese a ser testada pela análise é a de que essa autoconsciência age no filme por meio da preservação de uma certa opacidade da personagem em relação ao narrador do filme e ao espectador, opacidade por meio da qual a personagem mantém sua autonomia preservada.

Palavras-chave: Pedro Costa; Bakhtin; cinema português.

Abstract: This essay presents an analysis of the character Ventura, from colossal youth, in the light of Bakhtin's considerations about the construction of the character in Dostoievski's polyphonic novel. The text will focus mainly on Ventura's letter and on its possible analytical reading as a way to comment on the constitution of this character as a self-awareness. It is a hypothesis to be tested by the analysis that this self-awareness acts in the film through the preservation of a certain opacity of the character in relation to the narrator of the film and the spectator, opacity through which the character maintains his autonomy preserved.

Keywords: Pedro Costa; Bakhtin; portuguese cinema. 
Neste ensaio propomos a análise da personagem Ventura, de Juventude em marcha (2006), à luz das considerações de Bakhtin (2013) sobre a construção da personagem no romance polifônico de Dostoievski. Não se trata de verificar as considerações teóricas de Bakhtin no filme, como se esse fosse um exemplo delas, mas de utilizar os recursos oferecidos por sua análise do romance polifônico para enriquecer os comentários e a análise sobre essa personagem.

A análise se centrará, sobretudo, na carta de Ventura, repetida em diversas cenas ao longo do filme, e em sua possível leitura analítica como uma porta de entrada para comentarmos a constituição dessa personagem como uma autoconsciência. A hipótese a ser testada pela análise é a de que essa autoconsciência age no filme por meio da preservação de uma certa opacidade da personagem em relação ao narrador do filme (a entidade que organiza os planos, a montagem, a disposição da luz etc.) e ao espectador, opacidade por meio da qual a personagem mantém sua autonomia preservada.

Juventude em marcha é o último filme da chamada trilogia de Fontainhas, constituída também por Ossos (1997) e No quarto de Vanda (2000), ambos de Pedro Costa, denominada assim por nela assistirmos a uma espécie de arco da destruição do bairro de lata homônimo na periferia de Lisboa: no primeiro filme, não há nenhuma insinuação da demolição do bairro; no segundo, vemos as casas serem derrubadas e ouvimos os ruídos das máquinas de demolição; e, no último, resta apenas uma casa do antigo bairro, cuja população foi transferida para uma espécie de conjunto habitacional formado por prédios brancos, o Casal da Boba. Esse arco é reforçado por recorrências entre os três filmes, como, por exemplo, ao vermos que, da casa de uma personagem do primeiro filme, sobrou, no segundo, apenas seu portão azul.

Além do processo de destruição do bairro, é possível afirmar que essa trilogia também marca um ponto de inflexão na maneira como o realizador faz seus filmes. Do primeiro ao último, Pedro Costa abandona a película para adotar o vídeo, além de diminuir consideravelmente a equipe de produção e aumentar o tempo de filmagem, que, nesse caso, é também um tempo de convívio com os não-atores moradores do bairro que passam a compor integralmente o elenco. Esse convívio não é mencionado gratuitamente, pois se relaciona, por sua vez, com o abandono de uma ênfase na roteirização prévia à filmagem, ainda presente em Ossos, e uma maior abertura às sugestões do próprio filmado, como atesta a composição da carta que é objeto de atenção deste ensaio, de autoria partilhada entre Pedro Costa e Ventura (e baseada em uma carta de Robert Desnos) (JORGE, 2020).

É nessa inflexão que surge Ventura, protagonista do último filme da trilogia e que estará presente em produções até a próxima década, como Cavalo dinheiro (2014), 
de Pedro Costa, indicando uma continuidade entre Juventude em marcha e os filmes posteriores do realizador e reforçando essa ideia de transformação, de inflexão, operada entre os três filmes de Fontainhas.

A crítica esteve atenta a essa posição aparentemente privilegiada de Ventura na filmografia do realizador, com artigos comentando a relação entre sua figura e a câmera (NEYRAT, 2008), o aspecto deambulatório do personagem (FONSECA, 2008) ou a própria carta que repete ao longo do filme e que se repete entre os filmes - ela já havia aparecido em Casa de lava (1994), de Pedro Costa (FONSECA; RANCIÈRE, 2008).

Quanto a essa última, ela parece se apresentar como um elemento de circulação entre os personagens, de rima dentro do filme, cuja retomada se assemelha a um refrão, e de partilha, pois além do aspecto de múltipla autoria mencionado anteriormente, ela é recitada entre dois personagens. Pedimos um pouco da paciência do leitor para descrevermos brevemente cada um dos episódios em que há essa recitação, de modo que possamos esboçar alguns traços da configuração que a carta assume dentro do filme e na constituição de Ventura e sua relação com Lento.

Na primeira aparição da carta em Juventude em marcha, vemos também a primeira cena em que figuram Ventura e Lento. Após uma cena em um pequeno espaço interno, na qual os dois personagens de costas retiram seus chapéus e os colocam pendurados em uma parede de madeira, que se repetirá com leves alterações ao longo do filme, temos um diálogo, já em outro ambiente interno. Nele, Lento diz que precisa escrever uma carta "de matar saudade", "um tipo de carta de amor", pela ocasião do aniversário de uma mulher que se pressupõe a destinatária. Ventura, então, começa a recitação da carta,

Nha cretcheu, meu amor,

O nosso encontro vai tornar a nossa vida mais bonita por mais trinta anos. Pela minha parte, volto mais novo e cheio de força. Eu gostava de te oferecer 100.000 cigarros, uma dúzia de vestidos daqueles mais modernos, um automóvel, uma casinha de lava que tu tanto querias, um ramalhete de flores de quatro tostões. Mas antes de todas as coisas bebe uma garrafa de vinho do bom, e pensa em mim. Aqui o trabalho nunca pára. Agora somos mais de cem. Anteontem, no meu aniversário foi altura de um longo pensamento para ti. A carta que te levaram chegou bem? Não tive resposta tua. Fico à espera. Todos os dias, todos os minutos, aprendo umas palavras novas, bonitas, só para nós dois. Mesmo assim à nossa medida, como um pijama de seda fina. Não queres? Só te posso chegar uma carta por mês. Ainda sempre nada da tua mão. Fica para a próxima. Às vezes tenho medo de construir essas paredes. Eu com a picareta e o cimento. E tu, com o teu silêncio. Uma vala tão funda que 
te empurra para um longo esquecimento. Até dói cá ver estas coisas mas que não queria ver. $\mathrm{O}$ teu cabelo tão lindo cai-me das mãos como erva seca. Às vezes perco as forças e julgo que vou esquecer-me. (Juventude em marcha, 2006)

A recitação é interrompida por Lento na altura de "pensamento para ti", que diz não ter canetas, ao que Ventura responde “isso é triste”. Na sequência, com os dois deitados antes de dormir, Ventura continua a recitação e diz que a havia memorizado, a que Lento responde que é uma carta bonita.

Na próxima aparição, encontramos novamente Lento e Ventura deitados, mas, se antes esse parecia estar em uma cama alta, espécie de beliche, e apenas ele aparecia no quadro durante a recitação, agora vemos os dois deitados lado a lado, com a luz sobre os olhos abertos de Lento, ao passo que o rosto de Ventura está encoberto e sua voz soa como alguém que vacila antes de cair definitivamente no sono. Há um corte e uma mudança de cena, então vemos os personagens a andar próximos a uma janela com luz diurna e uma mesa sobre a qual garrafas tremem com os passos, enquanto a recitação da carta continua, sem ser possível distinguir se ocorre no momento da nova cena ou se é uma continuação da anterior, resultando numa indicação da recorrência da recitação, como se ela ocorresse continuamente e em momentos diferentes.

Antes da terceira recorrência da carta, vemos a cena do museu, comentada longamente por Rancière (2009). Após ser retirado do museu, há um diálogo entre Ventura e o segurança que havia lhe dirigido para fora, para um jardim, em que o espectador é informado sobre o acidente de Ventura, a queda do andaime sofrida durante as obras de construção do museu. Na sequência, vemos novamente a cena no pequeno ambiente em que Ventura e Lento costumam guardar seus chapéus. No entanto, dessa vez Ventura tem ligaduras na cabeça, e, a um canto, hesita, permanece imóvel e de cabeça baixa, ao que Lento retira com cuidado o chapéu de sua cabeça.

$\mathrm{Na}$ próxima cena vemos Ventura um pouco irascível, demandando de modo ríspido que Lento jogue cartas com ele. Ventura as lança com força na mesa, que produzem um estalo à maneira de um tapa. É assim que ele começa a terceira recitação da carta, pontuada pelos conselhos de Lento, "você precisa descansar", "não se canse", ou por sua ajuda, como num momento em que Ventura parece vacilar na sua memorização e Lento emenda a continuação da recitação: "fico à espera".

Lento, então, anuncia que havia comprado canetas e as tira do bolso da camisa, a que Ventura nada responde. Ele, inclusive, parece se esquivar dos comentários de Lento sobre seu acidente. Esse é o trecho do filme que coloca em 
dúvida a temporalidade das cenas anteriores que envolviam os dois personagens. Até então, as duas cenas anteriores se introduziram no filme sem nenhuma marca de distinção em relação ao tempo, de modo que não era possível distinguir se elas ocorriam simultaneamente às outras ações ou não, como as visitas de Ventura à Vanda, Bete ou os apartamentos vazios do conjunto habitacional. No entanto, ao introduzir as ligaduras de Ventura e as canetas de Lento, é possível pressupor que essas cenas entre os dois personagens são anteriores às outras ações, como atestado pelo diálogo da cena do museu, e que são sequenciais entre si.

Nas duas próximas aparições da carta, vemos o desenvolvimento do jogo de recorrências que parece se insinuar nesse "núcleo" (por falta de termo melhor) do filme. Na primeira, novamente temos as garrafas, dessa vez sob a luz de um lampião, numa composição com claros e escuros mais carregada que a anterior, construída com luz diurna, tremendo com os passos de Ventura que entra e sai de quadro, a recitar a carta sem a presença de Lento no enquadramento. Na próxima, vemos Lento sozinho na espécie de vestíbulo em que guardam os chapéus, indicando, talvez, que Ventura não tenha saído junto com ele para o trabalho. As duas cenas parecem conter, portanto, alguma cisão entre os personagens, o que irá se confirmar nas duas cenas posteriores.

Na primeira delas, vemos, com a câmera posicionada fora da casa em que habitam, Lento a tentar selar as janelas, com Ventura ao fundo ainda com as ligaduras. Pelo diálogo, Lento quer se proteger dos soldados, possivelmente da DGS (DireçãoGeral de Segurança), continuação da Pide, atiçados pela proximidade da Revolução dos Cravos; Ventura, por sua vez, diz que foi se confessar, e o padre lhe perguntou se comia carne humana. Há uma hostilidade inundando, portanto, a cena, que inibe a recitação da carta. Ventura lhe convida, que responde que agora a carta é inútil, impossível enviá-la para onde quer que fosse. Já na próxima cena, vemos Ventura a recitá-la frontalmente, quase a olhar para câmera, cercado por ripas de madeira que conferem à imagem uma ideia de moldura. Assim, ele parece a imagem de alguém que recita diante de um espelho. Lento, ao final, em outro enquadramento, deitado, responde "que carta feia".

Há ainda mais um encontro entre os personagens antes do último. Nele, Lento entra na casa, que parece ainda mais depauperada, e encontra Ventura parado sob o batente de uma porta, descalço. Ventura não responde à pergunta se havia comido, não dá passagem a Lento quando este pede licença, e apenas diz que o chão da casa treme. Ventura pergunta se Lento quer ouvir a carta, e este nega, em pé e com o corpo de lado, afirmando que ele não sabe ler e que Ventura nunca escreverá 
a carta. O quão distantes estamos das primeiras cenas, nas quais a carta era dita com voz baixa antes de dormir, com os personagens deitados, próximos e iluminados por um lampião? A carta já não é dita, os personagens parecem não se comunicar em sua verticalidade, parados cada qual sob um batente, uma moldura, na casa vacilante e fria. É nessa cena que Lento sofrerá o seu primeiro acidente, quando quis ligar eletricidade à casa para esquentá-la com um aquecedor.

A cisão parece que se aprofundava a cada cena envolvendo os dois personagens desde o acidente de Ventura. E não apenas a cisão entre eles, mas a cisão no próprio personagem, no próprio Ventura, que parece coincidir, nesse núcleo narrativo do filme, cada vez mais com a carta e com a impossibilidade dela se realizar (ser escrita, ser enviada, ser ouvida, ter interesse), tal como Lento coloca. Mas voltaremos a isso depois. O último encontro entre os personagens e, portanto, a última aparição da carta, no entanto, parece sinalizar algo contrário a essa cisão.

Vemos Lento e Ventura, esse sem as ligaduras, lado a lado em um apartamento chamuscado. O primeiro narra o incêndio, mostrando os cômodos da casa, e traz a marca ainda presente do incidente, as mãos queimadas, nas quais Ventura toca. Aos poucos, pelos diálogos, percebe-se que o apartamento fica no Casal da Boba, e que Ventura, logo que ouviu sobre o incêndio, veio ver Lento. Supõe-se, então, que nos encontramos não mais num tempo passado, mas na mesma temporalidade das outras ações do filme. Também pelo diálogo, somos informados que, diferentemente da cena das janelas seladas, em que havia a ameaça exterior dos soldados, o incêndio foi provocado internamente pelo próprio Lento. E, também, se nas cenas anteriores era Lento quem se ocupava das exigências das circunstâncias, em proteger a casa, em arranjar eletricidade, se o amigo havia comido e descansado, nessa cabe a Ventura a pergunta "e agora?". É ele também quem oferece uma "solução", a sua casa para Lento e sua família, como fez para aqueles que chama de seus filhos, o que coloca em dúvida o estatuto da relação entre os dois, se são amigos ou pai e filho, ou algo entre os dois, mais ou menos como ocorre com os outros personagens. E, para completar essa inversão, é Lento quem convoca a carta, recitando-a de mãos dadas com Ventura enquanto se retiram do apartamento queimado.

Seria isso uma reconciliação? Reconciliação do tempo, do encontro de um tempo outro das cenas dos dois personagens com o tempo do restante do filme, mas também reconciliação entre Ventura e Lento e de cada personagem consigo, ao tomar também para si a posição do outro? Se sim, é uma resposta, simultaneamente, sedutora e desconfortável, pois joga uma ternura, ainda que consumida pelas chamas e ferida, sobre um filme que tende a ser lido de maneira sombria pela crítica. Mas para seguir 
por esse caminho e evitar as suas ciladas, como a redução da dimensão crítica e política desse filme, que tem o estatuto ambíguo de saltar aos olhos e, ao mesmo tempo, ser tão difícil de ser apreendida, ser enunciada com justeza à sutileza de sua construção, temos que nos dedicar a algumas perguntas. Se há reconciliação, o que foi cindido anteriormente? Qual é a natureza dessa reconciliação e o que nela é reconciliado? Se há uma "ternura" nela, o que é essa ternura, do que ela é feita e a quem ela cabe?

Para esboçar um começo de resposta, é inevitável tratar da carta, que aparece em todas as cenas abordadas e pontua as nuances da relação entre os personagens. Como notamos anteriormente, ela surge a partir de uma demanda de Lento, mas aos poucos ele se afasta dela na mesma medida que as palavras de Ventura quase se limitam a ela, o que se acentua a partir do episódio após a queda do andaime. Vemos, a cada cena, Lento preocupado com os cuidados da casa e do amigo, e Ventura aferrado à carta, como na cena em que parece recitá-la diante de um espelho, como se os dois personagens já não partilhassem de um mesmo horizonte de comunicação e preocupação. É notável que em todas as cenas examinadas os dois personagens figuram num mesmo enquadramento, enfatizando a dimensão comunitária do cinema de Costa tal como indicada por Edson Pereira Costa Jr. (2018), com exceção dessa última. No entanto, cabe notar que a carta é um instrumento de partilha, e uma memorizada o é ainda mais, pois é feita para ser recitada; e a dimensão circunstancial, pragmática, por assim dizer, que ocupa Lento, não deixa de recobrir seu companheiro de cuidados. Dessa maneira, nesse aspecto mais centrado no enredo contido nessas cenas, na relação entre os dois personagens e nas ações, seria possível afirmar que a carta mantém a comunicação ao mesmo tempo que atesta a sua fragilidade entre personagens cuja relação já não se encontra cerrada no campo das palavras.

No entanto, essa é apenas a dimensão mais evidente da irreconciliação/ conciliação ao redor da carta. Notemos que ela e a demanda que lhe dá ensejo são já marcadas por uma separação, uma incomunicabilidade. Não só o texto da carta trata de uma distância que é seu propósito remediar ("uma carta de matar saudades"), mas também de uma ausência de resposta, assim como ela nunca poderá ser escrita e enviada. É digno de nota o seu eco na irreconciliação que marca o início do filme, com uma mulher, que Ventura acha semelhante a Clotilde, a mãe daqueles que chama de filhos, a deixá-lo, destruindo os móveis de sua casa. De maneira análoga à repetição da carta para Lento, seu amigo ou filho, vemos Ventura a contar da mulher que o deixou para "seus filhos". Então, de certa maneira, poderíamos afirmar que o encontro entre as diferentes temporalidades do filme mencionado na descrição da última cena é paralelo com o encontro entre as duas separações contidas em cada 
um dos tempos, da mesma maneira que a reconciliação com Lento por meio da carta seria paralela aos encontros com os filhos.

No entanto, ainda não chegamos nem perto do principal. E a relação de Ventura com a carta? Notamos, pela breve descrição das cenas acima, que as palavras de Ventura passam a se limitar cada vez mais à recitação da carta, e que, em uma dessas cenas, sua figuração chega a coincidir com essa recitação, como na cena do espelho. No entanto, percebemos no texto que a compõe e na situação que a suscita ao menos três aspectos: a irrealização, a separação e a incomunicabilidade, ao mesmo tempo que ela é dita diversas vezes na presença de um outro. Como poderíamos caracterizar, então, essa personagem que comunica sua incomunicabilidade, que, ao dizer, realiza o ato não realizado, que atesta sua separação, seu caráter apartado, na presença de um outro?

Por um caminho diverso, viemos a dar com o caráter inapreensível dessa personagem, como já havia sido ressaltado por Rancière (2009) a respeito da cena do museu. Segundo esse autor, Ventura é uma personagem que resiste a qualquer tentativa de redução sociológica ou psicológica, não serve para fazer eco às missões históricas atribuídas a esse ou aquele lugar social por um outro alguém, e estaria aí, para o autor, a sua potência. Se é uma personagem assim que resiste às abordagens, indecifrável, como vê-lo no filme? Pois ele parece se constituir de uma opacidade que resiste à tradução, a uma redução à nossa própria transparência, do espectador, assim como ocorre no seu trato com os outros personagens. No entanto, isso não impede que ele se relacione com os personagens que ficam um pouco hesitantes quando chamados de filhos, da mesma maneira que não impede que nós o "leiamos" num filme, ainda que seja de uma maneira muito particular a ser elucidada. Então, temos duas perguntas. Uma que cabe ao efeito de "leitura" do filme: como o opaco se torna legível sem ser traduzido? E uma que cabe à própria personagem: como ele se dá a ver e se mantém opaco? Como ele comunica a sua palavra sobre si, uma palavra cujo caráter problemático e lacunar é atestado pela carta, sem perder sua autonomia?

Um autor que pode nos ajudar a avançar sobre essas questões é Bakhtin, em seu texto O problema da poética de Dostoievski (2013), mais precisamente no capítulo 2, "A personagem e seu enfoque pelo autor na obra de Dostoievski". Analisando a constituição da personagem no romance polifônico do autor russo, Bakhtin chegará à noção da personagem enquanto autoconsciência. A novidade de Dostoievski, para Bakhtin, é justamente a capacidade de representar a consciência do outro, conservando sua autonomia enquanto consciência e mantendo, simultaneamente, a 
distância, sem assimilá-la à própria ideologia do autor. A consciência torna-se, mais que objeto, espécie de função da representação artística.

No entanto, vale lembrar que a imagem da consciência é inseparável da imagem do homem. O herói, em Dostoievski, é o homem de ideias, e, portanto, não se trata de traço social ou tipo psicológico, pois a ideia plenivalente que ocupa e é essa consciência que não pode se combinar com uma imagem acabada da personagem. O único que pode ser portador dessa ideia é o que Dostoievski chama de "homem no homem", o núcleo inacabado da personalidade da personagem. E isso se retroalimenta, uma vez que sendo a personagem alguém que procura resolver uma ideia em sua consciência, seu caráter inacabado coincide com o não fechamento que é condição da perseguição da ideia, do movimento de busca que constitui essa própria consciência.

A segunda condição da imagem da consciência em Dostoievski é a sua natureza dialógica. Somente quando contrai relações com as ideias dos outros é que consciência adquire vida, ou seja, desenvolve-se, e forma e encontra novas expressões verbais, a gerar novas ideias. Ao perder o caráter monológico, que diz respeito a apenas uma consciência, a ideia assume uma complexidade contraditória que age e se choca na relação com as consciências que a cercam. Mesmo nos monólogos interiores, não é apresentada nenhuma formação psicológica da ideia numa consciência fechada, pelo contrário, essa consciência se torna local de diálogo de diferentes ideias. Dorrit Cohn (1978) chamou atenção, alguns anos mais tarde e com outras preocupações, para essa situação aparentemente paradoxal do monólogo interior, da voz da consciência, que é o fato dele não abrir mão da exigência de um interlocutor. Fala-se consigo como se fosse a um outro, como se houvesse também uma plateia na intimidade de nossos pensamentos.

Vimos como a declamação de Ventura se coloca a meio caminho entre o monólogo e o diálogo, transitando ao longo das cenas entre um gesto de aproximação com Lento e a atestação do caráter apartado dos personagens. É digno de nota também como a disposição dos corpos se altera em cada cena, partindo de posições sentadas ao redor de uma mesa, passando pela horizontalidade das camas postas lado a lado no espaço figurado, até o isolamento no enquadramento e a verticalidade emoldurada pelos batentes, chegando, enfim, nas figuras em pé, mas que se tocam, como na cena da casa queimada. De qualquer maneira, se evidente nas cenas em que há uma maior disjunção entre os personagens, a carta acena que mesmo no seu gesto de aproximação já há um caráter problemático, irrealizado que ambos os personagens assumem no seu ato comunicativo. Todavia, Ventura e a carta ecoam um no outro à medida que a missiva é uma busca por comunicação e sua 
impossibilidade, o que a impulsiona à repetição e atesta também sua inconclusão, seu caráter inacabado. No entanto, o que isso pode nos informar sobre a autonomia e a opacidade mencionadas acima? Continuemos com Bakhtin.

Para o autor, a personagem interessa a Dostoiévski enquanto ponto de vista específico sobre o mundo e sobre si mesma. De certa maneira, não importa o que a sua personagem é no mundo, mas o que o mundo é para a personagem e o que ela é para si mesma. Dessa maneira, a sua construção não se dá pelo ser determinado da personagem, como uma imagem rígida, mas o movimento contínuo de sua consciência, que sustenta e adia "a última palavra da personagem sobre si mesma e sobre seu mundo" (BAKHTIN, 2013, p. 48). Não são, portanto, os "traços da realidade" que constituem a representação da personagem, mas o que essa personagem faz de tais traços na constituição da imagem que tem de si, nas operações e construção da sua autoconsciência. Em Dostoiévski, a posição social, a tipicidade sociológica ou psicológica, inclusive a sua aparência, não podem concluir e oferecer uma imagem acabada da personagem, "dar uma resposta artística à pergunta: "quem é ela?" (BAKHTIN, 2013, p. 49). Não se trata, então, de descobrir quem é a personagem, mas de que modo ela é personagem, como se relaciona com a sua palavra sobre si mesma. Assim, a pergunta "quem é ela?" torna-se objeto da própria consciência da personagem, e é essa consciência procurando por si mesma que constitui o objeto da representação artística.

Fica evidente, portanto, que a autoconsciência não pode ser apenas um traço adjetivo da personagem, que viria somar a sua imagem acabada, mas a própria personagem enquanto forma, forma que absorve os traços como matéria sua e impede que eles venham a concluir a personagem numa imagem estável. Tratava-se, em Dostoievski, de uma personagem que fosse concentrada na função de tomar consciência de si mesma no mundo. Como coloca Bakhtin,

O "homem do subsolo" não só absorve todos os possíveis traços estáveis da sua imagem, tornando-os objeto de reflexão; nele esses traços desaparecem, não só há definições sólidas, dele nada se tem a dizer, ele não figura como um homem inserido na vida mas como sujeito da consciência e do sonho. Para o próprio autor ele não é agente de qualidades e propriedades que possam ser neutras em relação à autoconsciência e coroá-la; a visão do autor está voltada precisamente para a autoconsciência e para a irremediável inconclusibilidade, a precária infinitude dessa autoconsciência. (2013, p. 52) 
Dessa maneira, a personagem se torna relativamente livre e independente, pois tudo aquilo que a tornava definida, que a caracterizaria de uma vez por todas como imagem acabada, passa agora a funcionar como material de sua consciência em processo. Assim, a personagem pode não coincidir consigo mesma em nenhum momento. É desse modo que a tipificação mencionada por Rancière não cabe a essa personagem. Sua localização social, a definição psicológica da interioridade, os possíveis traços morais de sua personalidade, entram em jogo na consciência de si da personagem, num movimento contínuo de busca e dissipação da definição, movimento inconcluso que é a própria consciência. E o que a representação da personagem procura construir é justamente a palavra dessa personagem sobre si.

Para Bakhtin, esse modo de representação da personagem enquanto autoconsciência traz um elemento ético evidente. Para Dostoiévski, em qualquer pessoa "sempre há algo que só ela mesma pode descobrir no ato livre da autoconsciência e do discurso, algo que não está sujeito a uma definição à revelia, exteriorizante" (BAKHTIN, 2013, p. 60). E, da mesma maneira, a autoconsciência é justamente a busca por essa palavra, de tal modo que ela nunca pode ser concluída e, assim, uma pessoa nunca coincide consigo mesma, não se pode aplicar a ela a forma da identidade pronta e acabada. Trata-se de um processo de subjetivação contínuo. Como coloca Bakhtin (2013, p. 61), "a autêntica vida do indivíduo se realiza como que na confluência dessa divergência do homem consigo mesmo, no ponto em que ele ultrapassa os limites de tudo $[\ldots]$ previsto "à revelia”, a despeito de sua vontade".

Bem, mas como isso pode nos ajudar na aproximação analítica da personagem Ventura? Vimos como há em Ventura, nas cenas da carta, uma certa opacidade e incomunicabilidade da palavra sobre si. Mas como isso se relaciona com a autoconsciência e com a autonomia? E com a ideia? Em relação a essa primeira, o comentário que podemos oferecer, baseado na descrição das cenas, é mais evidente. Ventura, ao se constituir como a repetição da carta, toma o caráter de uma ideia, a ideia contida nela e, simultaneamente, que é a carta mesma dentro do pequeno enredo das cenas com Lento: a irrealização, a incomunicabilidade, a distância, e o canto desses três elementos constituído por sua repetição.

Mas é possível constituir uma autoconsciência autônoma a partir disso? Vale lembrar que em Juventude em marcha parece estar ausente o espírito rixoso tão marcante de Dostoievski. Como coloca Bakhtin sobre o universo desse autor, "nenhum elemento de semelhante clima pode ser neutro: tudo deve atingir o herói em cheio, provocá-lo, interrogá-lo, até polemizar com ele e zombar dele” (2013, p. 66). No entanto, ao contrário do homem do subsolo, que procura defender 
a palavra sobre si da rapina dos outros, Ventura tende mais ao balbucio ou à recitação paciente da carta, tende a oferecer a palavra de si ao outro, e o narrador a preservar, e não a avançar sobre a palavra da personagem. A última palavra de Ventura é uma hesitação, uma gagueira, uma repetição? Qual é a última palavra de Ventura sobre si?

Primeiramente, como vimos, cabe apenas à própria personagem sustentar essa pergunta, e já está aí sua autonomia, o que o livra de um pleno entendimento cabal por parte do espectador, do realizador e dos demais personagens. Por outro lado, se admitirmos que um dos traços visíveis dessa palavra é a carta, cuja repetição é o próprio movimento dessa autoconsciência, repetição que busca e refuta a palavra final e sua partilha com o outro simultaneamente, temos que a palavra de Ventura sobre si carrega já em sua matéria, em seu movimento, a inconclusibilidade e a irrealização. Talvez esse possa ser um princípio de resposta para a pergunta que fizemos acima, sobre como manter a visibilidade e a autonomia da personagem lado a lado.

Quanto à outra pergunta, sobre a legibilidade daquilo que é opaco, talvez a última cena com Lento possa nos oferecer uma pista. Vimos como ele parece desistir da carta, perde seu interesse por ela, e com isso assinalamos uma possível cisão entre os personagens, como se o horizonte de comunicação entre eles houvesse sido perdido, tomando a cena do espelho como paradigmática desse rompimento ao nível da palavra. Todavia, é por meio da palavra, da recitação da carta na boca de Lento que haverá a reconciliação das cenas, reconciliação que ocorre em muitos níveis, como foi indicado. Lado a lado, de mãos dadas, não é como se Lento houvesse escrito e assinado a carta com seu nome, mas a sua recitação aproxima os personagens, coloca-os em relação. Não houve violação da última palavra de Ventura, uma "definição à revelia", mas ao tomar a carta como a própria inconclusibilidade dessa personagem, Lento pode tocá-lo.

O espectador poderia se colocar também nessa posição? Poderia ele, à maneira de Lento, ao assumir a autonomia dessa inconclusibilidade, se aproximar de Ventura, partilhar com eles disso a que chamamos ternura? Não era exatamente disso que tratava Bakhtin no texto comentado, mas para ele o autor se relaciona com a personagem inacabada não por um "ele", nem um "eu", mas por um "tu”, isto é, a autoconsciência plenivalente de um outro presente. Então, extrapolando esse comentário, poderíamos colocar o espectador como uma autoconsciência ao lado dessas personagens?

Se sim, seria uma resposta feliz. No entanto, o registro que aparentemente Pedro Costa inaugurou com esse filme é muito mais complicado. Basta apontarmos o comentário de Mateus Araújo sobre Juventude em marcha. O autor (2008) menciona 
um realismo específico de Pedro Costa ao relacionar a exiguidade dos planos e dos espaços nos filmes com o aprisionamento simbólico e a limitação imposta às perspectivas dos pobres e imigrantes. Ao não tornar a prisão visível nos filmes, mas apenas como que a insinuar, coloca-se o espectador como o responsável por efetivar essa relação, por remeter os personagens à prisão que pousa sobre o filme, colocando-o, portanto, numa posição análoga àqueles que mandam as pessoas para a prisão ou que tornam a vida delas um cativeiro. O espectador acaba por tomar, simbolicamente, a parte que lhe caberia nessa situação. Dessa maneira, a dimensão carcerária seria ainda mais enfática, pois exigiria a implicação do espectador e a execução simbólica da prisão ocorreria por meio da elaboração simbólica operada pelo espectador dos recursos do filme.

É possível acrescentar ainda, considerando a maneira como caracterizamos a carta de Ventura, uma dimensão eminentemente traumática nesse registro de representação, que será comentada brevemente em seguida. Se considerarmos que os filmes de Pedro Costa não colocam "em relação", ou seja, não apresentam o outro lado (a polícia, a exploração) que causaria e explicaria a situação dos personagens, assim também como não apresentam o evento do choque (a queda de Ventura do andaime, por exemplo), parece que eles se instalam nessa dimensão do deferido, do lacunar, e da opacidade familiar ao léxico do aberto e inconcluso, mas também do trauma: a repetição da linguagem e a resistência à significação, o encontro com outro continuamente deferido, mas que procura, na sua incompletude, se elaborar por meio da palavra, a hostilidade que paira sobre os corpos. A violência não é encenada, não vemos as forças que pesam sobre as condições precárias da vida em Fontainhas em exercício explícito, o que não impede que a violência do desalojamento, da imigração, da partida esteja presente e seja reelaborada continuamente pela palavra.

Sabemos que na tradição da representação (seria melhor dizer da nãorepresentação) do trauma, o testemunho ocupa um lugar privilegiado, trazendo consigo a questão da indeterminação. Basta lembrarmos os filmes de Rosselini, com os campos vazios e o mato alto por entre a cerca, ou a distinção entre a personagem que vai, por conta própria, ver o outro lado, o subúrbio, e perde a si, a palavra de si, e a personagem que se coloca na posição de explicar esse outro lado, de submeter o outro e o trauma a sua capacidade explicativa (a figura do cunhado jornalista em Europa 51 (1952), de Roberto Rossellini, aquele que "coloca em relação", liga diretamente o subúrbio à sua mesa no jornal, explica, com suas palavras, as palavras da criança que se mata, ou seja, aquele que pode levar a sério, justamente porque já sabe a resposta de antemão, a pergunta obscena "por que alguém se mata?") (RANCIÈRE, 2003). 
No entanto, esse recuo diante da significação poderia ser entendido por meio de um recuo na representação que daria a ver uma personagem, por exemplo, com a menor mediação possível? É digno de nota que muito autores colocam a presença do real em oposição à significação, como por meio de um real traumático cujo encontro é continuamente deferido, como articula Foster (2014). Mas, se assim fosse, como dar a ver o real sem significação por meio de uma representação, uma operação simbólica que, como tal, inevitavelmente está atravessada de sentidos? Talvez fazendo com que o real não seja o endereço a que se destina a operação simbólica, mas um produto da própria lógica dessa operação.

Assim, é necessário indicar uma primeira ressalva que poderia se colocar ao que estamos esboçando como uma representação da não significação: ela não trairia sua própria intenção? Se um dos interesses na representação realista é que o "mundo esteja lá", que ele seja tangível, como coloca Foster, por outro lado, sem a possibilidade de manipulação artística, de expressividade, ela pouco teria a nos dizer sobre ele. Como coloca Arlindo Machado, "a simples réplica do mundo visível, exposta tal e qual, sem nenhuma mediação, não nos dá qualquer informação importante sobre a realidade" (1984, p. 40). Porque a representação de um objeto é a representação de uma ação pessoal sobre o objeto, que se realiza na manipulação formal de como se constrói essa representação específica, por meio da qual, inclusive, se constitui a relação dessa representação com as outras, sua diferenciação e especificidade que a localiza em relação à história daquela tradição representativa e de outras formas de representação. Nas palavras de Machado,

Nós seríamos incapazes de registrar uma realidade se não pudéssemos ao mesmo tempo criá-la, destruí-la, deformála, modificála: a ação humana é ativa e por isso as nossas representações tomam a forma ao mesmo tempo de reflexão e refração. [...] não pode ser o registro puro e simples de uma imanência do objeto: como produto humano, ela cria também com esses dados luminosos uma realidade que não existe fora dela, nem antes dela, mas precisamente nela. (1984, p. 40)

Dessa maneira, nos filmes de Pedro Costa, se há o realismo da violência traumática e se há o recuo da significação, eles são agenciados por um tratamento muito específico do diálogo, dos enquadramentos, da disposição dos personagens, elementos que procuramos analisar. Além do mais, Mateus Araújo não deixa de observar que o realismo que aponta é dependente de uma operação do espectador sobre o filme, ou seja, de uma mediação que vai além da mera identificação de "um mundo que está lá". 
Todavia, se é possível a ternura que mencionamos acima conviver com essa leitura traumática do filme, se elas podem se encontrar e como podem se encontrar, não temos a capacidade para avançar mais. Por enquanto, são pistas recolhidas num pequeno inventário. Fazemos eco à afirmação de que Pedro Costa inaugurou um novo registro fílmico em Juventude em marcha, mas se trata-se de um novo realismo e qual é seu estatuto, não sabemos. No entanto, a sutileza e o cuidado discreto com que dá a ver as autoconsciências em jogo exigem que avancemos devagar, tateantes, no duplo sentido da palavra, como quem toca e hesita.

Por fim, arriscaremos alguns comentários sobre esse encontro, procurando dar contornos mais nítidos ao que aqui foi chamado de ética do inconcluso, fórmula fugidia perseguida ao longo do texto. Vamos retomar a dimensão ética apontada no comentário sobre Bakhtin. Vimos como esse termo se baseia numa espécie de reserva, de recuo da instância enunciadora em relação aos personagens, que, dessa maneira, teriam sua autonomia preservada no exercício pleno de sua própria inconclusão. Diferente do que poderia ser entendido como política, uma ação comunicativa propositiva no seio de uma comunidade, a ética, tal como aqui colocada, é antes uma condição comunicativa baseada na reserva: mais do que endereçar a palavra a outros, uma postura que possibilitaria o exercício contínuo da palavra do outro. Inclusive, aqui poderia se buscar a relação entre violência traumática e inconclusão: contra o que exatamente essa reserva procura defender a autonomia da personagem? Mais especificamente, a inconclusibilidade de Ventura defende sua autonomia diante de quais forças heterônomas? Questões para desenvolvimento futuro.

Retomando, lembremos o que esse recuo implica: a inconclusão e a indeterminação da personagem, que lhe permite, por um lado, resistir a qualquer definição à revelia e, por outro, se manter em contínuo movimento, em liberdade ao menos quanto à própria palavra de si. De maneira análoga, a opacidade, a intraduzibilidade, de uma personagem teria o mesmo efeito sobre o espectador, resistindo à redução ao seu entendimento. Esse teria que, ao longo do filme, conviver com essa autoconsciência autônoma. Sem identificação ou outra porta de entrada, não restaria ao espectador nada além de se colocar lado a lado com os personagens, de se manter, em relação ao filmado, como uma entidade autônoma. Aqui vem à lembrança a noção de cotidiano formulada por Blanchot (2010), segundo a qual o cotidiano é aquilo que não se deixa apanhar, é o mais difícil de se descobrir. $\mathrm{O}$ cotidiano não oferece nenhuma porta de entrada, no entanto, da mesma maneira, também nunca saímos do cotidiano.

O espectador não adentra naquela ternura mencionada acima, a meio caminho entre um tratamento documental e ficcional do cotidiano, ternura partilhada 
pelos dois personagens, elaborada por eles à volta da carta que partilham à sua maneira, mas também construída sob escombros e catástrofes, soterrados pela prisão. No entanto, talvez o espectador possa se colocar ao lado dessa ternura, ouvir e ver e senti-la - sem entendê-la, sem tomá-la para si. Assim, também essa ternura pode se colocar sem trair a precariedade e a violência que pairam sobre o filme. Não há concessão ao espectador, a parte que lhe cabe, simbolicamente, no sufocamento do universo filmado é um dos efeitos do filme; mas, ao mesmo tempo, a autoconsciência irredutível de Ventura coloca o espectador também como autoconsciência, e assim pode lhe assaltar tanto a percepção da ternura, da dignidade dos personagens em sua autonomia para além das categorias, como a constatação de que "o mundo é uma prisão". E também instala o espectador num regime traumático, pois seu encontro com os personagens, se colocarmos encontro como entendimento, é continuamente deferido, irrealizado, ainda que, simultaneamente, seja convocado a vê-los. Além da ética da inconclusão dos personagens, teríamos uma ética generosa em relação ao espectador, justamente porque não lhe faz nenhuma concessão e, assim, evitando as ciladas de uma identificação traidora, o coloca lado a lado com os personagens em sua autonomia, com o mundo em ruína e com o tratamento traumático do filmado.

A ética do inconcluso em Juventude em marcha seria caracterizada por uma forma, aqui comentada sobretudo por meio da análise dos diálogos e da distribuição dos corpos no espaço figurado, que engendra uma postura de recuo em relação à personagem Ventura, recuou que preservaria a sua autonomia frente a uma redução à transparência do espectador e o movimento contínuo de sua palavra sobre si frente ao cerramento das possibilidades colocadas aos imigrantes pobres representado pelo soterramento prisional comentado ao longo do artigo.

Pode parecer pouco, a indeterminação. Mas se considerarmos figuras que são submetidas constantemente à objetificação, como os homens pobres, a indeterminação pode ser algo, um começo de algo, pode ser o reconhecimento de sua dignidade para além das categorias, de que um outro não pode alcançar determiná-los, de que essa determinação é falsa... pode ser um recuo do narrador, mas um recuo que abre mão de falar sobre para poder falar perto. E um convite ao espectador para se colocar junto.

\section{Referências}

BAKHTIN, M. O problema da poética de Dostoievski. Rio de Janeiro: Forense, 2013.

BLANCHOT, M. “A fala cotidiana”. In: BLANCHOT, M. A conversa infinita 3 - a ausência de livro. São Paulo: Escuta, 2010. 
COHN, D. Transparent minds: narrative modes for presenting consciousness in fiction. Princeton University Press, 1978.

COSTA JÚNIOR, E. P. A figura humana no cinema: matéria, desejo e comunidade. 2018. 297 p. Tese (Doutorado) - Escola de Comunicação e Artes, Universidade de São Paulo, São Paulo, 2018.

FONSECA, J. T. “A recusa do esquecimento inevitável”. Devires, Belo Horizonte, v. 5, n. 1, p. 16-26, 2008.

FOSTER, H. O retorno do real: a vanguarda no final do século XX. Tradução de Célia Euvaldo. São Paulo: Cosac Naify, 2014.

JORGE, N. B. ReFocus: the films of Pedro Costa - producing and consuming contemporary art cinema. Edinburgh: Edinburgh University Press, 2020.

MACHADO, A. A ilusão especular. São Paulo: Brasiliense, 1984.

NEYRAT, C. "Passo de gigante”. Tradução de Mateus Araújo Silva. Devires, Belo Horizonte, v. 5, n. 1, p. 112-122, 2008.

RANCIÈRE, J. “A carta de Ventura”. Devires, Belo Horizonte, v. 5, n. 1, p. 104-111, 2008.

RANCIÈRE, J. “Política de Pedro Costa”. In: CABO, R. M. (org.). Cem mil cigarros os filmes de Pedro Costa. Lisboa: Orfeu Negro, 2009.

RANCIÈRE, J. Short voyages to the land of the people. Stanford University Press, 2003.

SILVA, M. "Pedro Costa e sua poética da pobreza". Devires, Belo Horizonte, v. 5, n. 1, 2008.

\section{Referências audiovisuais}

JUVENTUDE em marcha. Pedro Costa, Portugal, 2006.

NO QUARTO da Vanda. Pedro Costa, Portugal, 2000.

OSSOS. Pedro Costa, Portugal, 1997.

submetido em: 10 nov. 2020 | aprovado em: 06 abr. 2021 